\title{
Antimicrobial peptide scolopendrasin VII, derived from the centipede Scolopendra subspinipes mutilans, stimulates macrophage chemotaxis via formyl peptide receptor 1
}

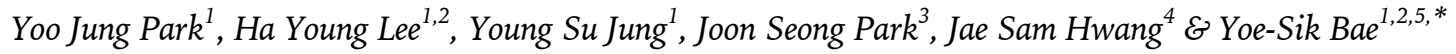 \\ ${ }^{1}$ Department of Biological Sciences, Sungkyunkwan University, Suwon 16419, ${ }^{2}$ Mitochondria Hub Regulation Center, Dong-A University, \\ Busan 49201, ${ }^{3}$ Department of Hematology-Oncology, Ajou University School of Medicine, Suwon 16499, ${ }^{4}$ Department of Agricultural \\ Biology, National Academy of Agricultural Science, RDA, Wanju 55365, ${ }^{5}$ Department of Health Sciences and Technology, SAIHST, \\ Sungkyunkwan University, Seoul 06351, Korea
}

\begin{abstract}
In this study, we report that one of the antimicrobial peptides scolopendrasin VII, derived from Scolopendra subspinipes mutilans, stimulates actin polymerization and the subsequent chemotactic migration of macrophages through the activation of ERK and protein kinase B (Akt) activity. The scolopendrasin VII-induced chemotactic migration of macrophages is inhibited by the formyl peptide receptor 1 (FPR1) antagonist cyclosporine $\mathrm{H}$. We also found that scolopendrasin VII stimulate the chemotactic migration of FPR1-transfected RBL-2H3 cells, but not that of vector-transfected cells; moreover, scolopendrasin VII directly binds to FPR1. Our findings therefore suggest that the antimicrobial peptide scolopendrasin VII, derived from Scolopendra subspinipes mutilans, stimulates macrophages, resulting in chemotactic migration via FPR1 signaling, and the peptide can be useful in the study of FPR1-related biological responses. [BMB Reports 2015; 48(8): 479-484]
\end{abstract}

\section{INTRODUCTION}

Formyl peptide receptors (FPRs) are important chemoattractant G-protein coupled receptors (GPCRs) that mediate the chemotactic migration of leukocytic cells $(1,2)$. Several different myeloid leukocytes such as neutrophils, monocytes, macrophages, and dendritic cells express functional FPRs. The activation of FPRs in neutrophils and monocytes elicits superoxide anion production and bactericidal activity $(1,3)$. FPRs are involved in the negative regulation of dendritic cell maturation induced by lipopolysaccharide (LPS) or tumor necrosis factor

*Corresponding author. Tel: +82-31-290-5914; Fax: +82-31-2907015; E-mail: yoesik@skku.edu

http://dx.doi.org/10.5483/BMBRep.2015.48.8.115

Received 16 June 2015, Revised 29 June 2015, Accepted 1 July 2015

Keywords: Antimicrobial peptide, Chemotaxis, Formyl peptide receptor 1, Macrophage, Scolopendrasin VII
(TNF)- $\alpha$ (4). We also reported that natural killer cells express functional FPRs that regulate chemotactic migration, interferon (IFN)- $\gamma$ production, and cytolytic activity (5).

Unlike other chemokine or chemoattractant receptors, FPRs recognize a diverse variety of ligands such as formyl peptides derived from bacteria, formyl peptides derived from mitochondria, and host-derived agonists (serum amyloid A, annexin A4, LL-37, and humanin) $(1,2)$. One of the FPR members FPR2 also recognizes the lipid-derived eicosanoid lipoxin A4 (6). Among these FPR agonists, LL-37 is an important antimicrobial peptide (AMP) that is capable of killing bacteria (7). We are particularly interested in the finding that an AMP (LL-37) is capable of achieving chemotactic migration via the stimulation of leukocytic cells. Since chemotactic migration of leukocytes into event (infection or injury) areas is important to regulate immune or inflammatory response, the identification of new molecules that regulate leukocyte chemotaxis has received attention.

Previously we reported on several AMP candidates using de novo RNA sequencing from Scolopendra subspinipes mutilans, and demonstrated that some of the AMPs showed anticancer activity in leukemia cells $(8,9)$. In this study, we investigated whether AMPs that have been isolated from the centipede may regulate macrophage activity. We demonstrated that an AMP isolated from the centipede stimulates mouse bone marrow-derived macrophages (BMDMs), resulting in chemotaxis. We also showed that FPR1 is the target receptor for the AMP.

\section{RESULTS}

Scolopendrasin VII stimulates BMDM chemotactic migration via pertussis toxin (PTX)-sensitive G-protein

Based on the previous report that an AMP LL-37 stimulates leukocyte chemotaxis via cell surface receptor (7), we also tried to see if we can extend the effect of AMP on leukocyte migration with other AMP. To investigate the putative effect of scolopendrasin VII on macrophage activity, we tested whether scolopendrasin VII regulates chemotactic migration in the cells. The

ISSN: 1976-670X (electronic edition)

Copyright (C) 2015 by the The Korean Society for Biochemistry and Molecular Biology

(c) This is an open-access article distributed under the terms of the Creative Commons Attribution Non-Commercial License (http://creativecommons.org/licenses/by-nc/4.0) which permits unrestricted non-commercial use, distribution, and reproduction in any medium, provided the original work is properly cited. 
A

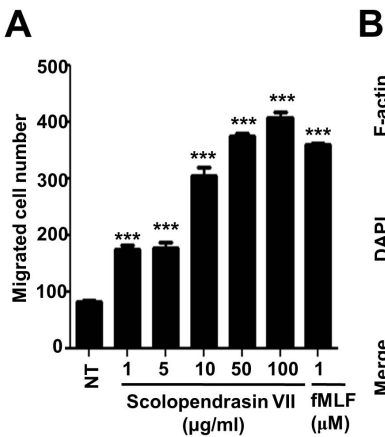

B

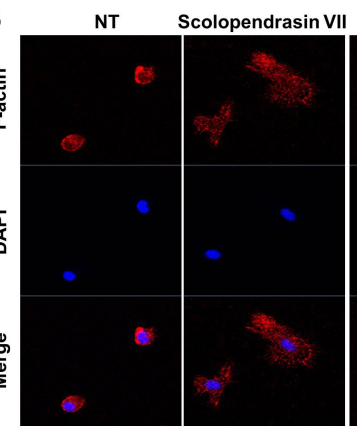

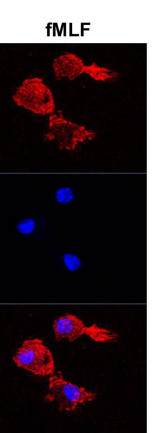

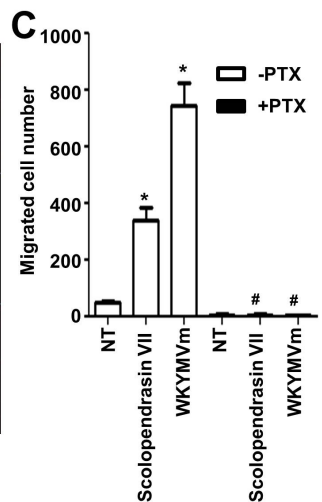

Fig. 1. Scolopendrasin VII stimulates BMDM chemotaxis via PTX-sensitive G-protein. (A) Mouse BMDMs were applied to the upper well of the multiwell chamber containing several concentrations $(0 \mu \mathrm{g} / \mathrm{ml}, 1 \mu \mathrm{g} / \mathrm{ml}, 5 \mu \mathrm{g} / \mathrm{ml}, 10 \mu \mathrm{g} / \mathrm{ml}, 50 \mu \mathrm{g} / \mathrm{ml}, 100 \mu \mathrm{g} / \mathrm{ml})$ of scolopendrasin VII or 1 $\mu \mathrm{M}$ of $\mathrm{fMLF}$ for $2 \mathrm{~h}$. (B) Mouse BMDMs were stimulated with $100 \mu \mathrm{g} / \mathrm{ml}$ of scolopendrasin VII or $1 \mu \mathrm{M}$ of fMLF for 2 min. Polymerized actin were visualized by staining with rhodamine-phalloidin. Nuclei were stained with DAPI. Data are representative of three independent experiments (B). (C) Mouse BMDMs were incubated in the absence or presence of $100 \mathrm{ng} / \mathrm{ml}$ PTX for $24 \mathrm{~h}$, and were applied to the upper well of the multiwell chamber containing $100 \mu \mathrm{g} / \mathrm{ml}$ of scolopendrasin VII or $1 \mu \mathrm{M}$ of WKYMVm for $2 \mathrm{~h}$. The number of migrated cells was determined by counting under a light microscope. Data are presented as means \pm S.E. ${ }^{*} \mathrm{P}<0.05, * * * \mathrm{P}<0.001$ compared to the NT (not treated) control; \# $\mathrm{P}<0.05$ compared to the $-\mathrm{PTX}$ control.

scolopendrasin VII strongly induced the chemotactic migration of the BMDMs, showing a concentration-dependency (Fig. 1A), and the $50 \mu \mathrm{g} / \mathrm{ml}$ scolopendrasin VII-induced BMDM chemotactic migration is comparable with the migration induced by the $\mathrm{FMLF}$, a well-known potent chemoattractant for BMDM (Fig. 1A). Since actin polymerization is accompanied with the chemotactic migration of leukocyte (10), we tested the effect of scolopendrasin VII on actin polymerization by staining the cells with rhodamine-phalloidin, which specifically binds to polymerized actin. The stimulation of the BMDMs with scolopendrasin VII induced actin polymerization (Fig. 1B). The results suggest that scolopendrasin VII stimulates BMDMs, resulting in chemotactic migration via actin polymerization.

In previous reports, chemokines and chemoattractants stimulated the chemotactic migration of leukocytic cells via PTX-sensitive G-protein(s) $(1,11)$. In this study we examined the role of the PTX-sensitive G-protein in scolopendrasin VII-induced chemotaxis. Incubation of the BMDMs with PTX prior to the addition of scolopendrasin VII almost completely inhibited the scolopendrasin VII-induced chemotactic migration of the BMDMs (Fig. 1C). PTX also completely inhibited WKYMVm (a well-known synthetic FPR agonist)-induced chemotaxis (Fig. 1C). The results suggest that PTX-sensitive GPCRs may be involved in the process.

\section{Scolopendrasin VII stimulates ERK and protein kinase B (Akt) activity in BMDMs}

Because scolopendrasin VII stimulated the chemotactic migration of BMDMs, we examined the signaling pathways involved in the peptide-induced chemotaxis. Many chemokines and chemoattractants that bind to PTX-sensitive GPCRs stimulate
A

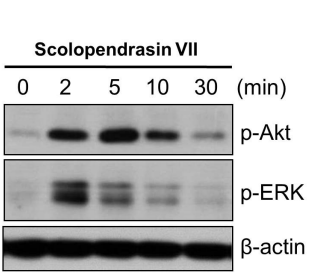

B

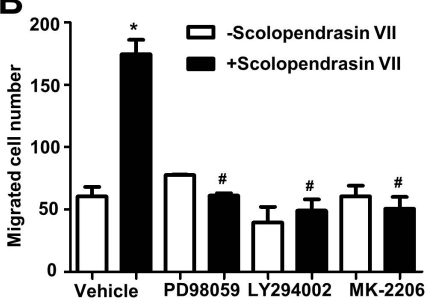

Fig. 2. Scolopendrasin VII stimulates Akt and ERK activity in BMDMs. (A) Mouse BMDMs were stimulated with $100 \mu \mathrm{g} / \mathrm{ml}$ of scolopendrasin VII for several lengths $(0 \mathrm{~min}, 2 \mathrm{~min}, 5 \mathrm{~min}, 10 \mathrm{~min}$, $30 \mathrm{~min}$ ) of time. Total cell lysates were separated in SDS-PAGE, and the levels of p-Akt and p-ERK were measured using a Western blot analysis. Data are representative of three independent experiments (A). (B) Mouse BMDMs were incubated in the absence or presence of PD98059 $(50 \mu \mathrm{M})$ for $60 \mathrm{~min}$, LY294002 (50 $\mu \mathrm{M})$ for $15 \mathrm{~min}$, or MK-2206 (2 $\mu \mathrm{M})$ for $20 \mathrm{~min}$, and were applied to the upper well of the multiwell chamber containing $100 \mu \mathrm{g} / \mathrm{ml}$ of scolopendrasin VII for $2 \mathrm{~h}$. The number of migrated cells was determined by counting under a light microscope. Data are presented as means \pm S.E. ${ }^{*} P<0.05$ compared to the NT (not treated) control; ${ }^{\#} \mathrm{P}<0.05$ compared to the scolopendrasin VII alone control.

phospholipase $\mathrm{C}$ activity and the subsequent increase of intracellular calcium $(1,12)$. We checked whether scolopendrasin VII stimulates calcium increase in the BMDMs using fura-2 labeled cells; the stimulation of the fura-2 loaded BMDMs with scolopendrasin VII did not induce an intracellular calcium increase (data not shown).

Mitogen-activated protein kinases (MAPKs) such as ERK, p38 MAPK, and JNK are activated by chemokine or chemoattractant 
receptors $(1,13)$. To see whether scolopendrasin VII stimulates MAPKs in BMDMs, we performed a Western blot analysis. Stimulation of the BMDMs with scolopendrasin VII also induced a transient ERK phosphorylation that was apparent in the region of 2 min to 10 min after stimulation (Fig. 2A); however, scolopendrasin VII did not stimulate p38 MAPK and JNK phosphorylation in the BMDMs (data not shown). Akt is an important enzyme that mediates a diverse range of cellular responses including proliferation, survival, and migration (14). We also examined the effect of scolopendrasin VII on Akt activity by monitoring the phosphorylated level of Akt after the scolopendrasin VII stimulation. Scolopendrasin VII strongly increased the Akt phosphorylation level in a time-dependent manner, showing marked activity in the region of $2 \mathrm{~min}$ to 10 min after stimulation (Fig. 2A).

Since scolopendrasin VII stimulated ERK and Akt activity in
A

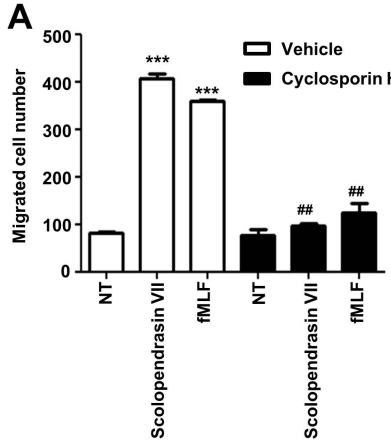

B

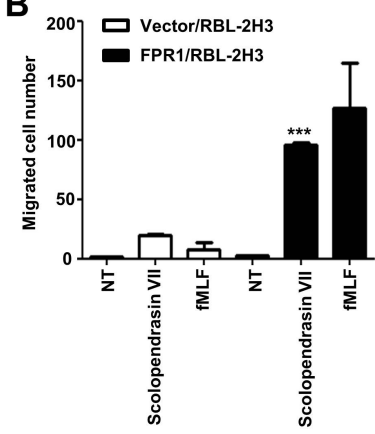

Fig. 3. Scolopendrasin VII-induced BMDM chemotaxis is mediated by FPR1. (A) Mouse BMDMs were incubated in the absence or presence of cyclosporin $\mathrm{H}(1 \mu \mathrm{M})$ for $30 \mathrm{~min}$, and were applied to the upper well of the multiwell chamber containing $100 \mu \mathrm{g} / \mathrm{ml}$ of scolopendrasin VII or $1 \mu \mathrm{M}$ of fMLF for $2 \mathrm{~h}$. (B) Vector- or FPR1-expressing RBL-2H3 cells were applied to the upper well of a multiwell chamber containing $100 \mu \mathrm{g} / \mathrm{ml}$ of scolopendrasin VII or $1 \mu \mathrm{M}$ of $\mathrm{fMLF}$. The number of migrated cells was determined by counting under a light microscope. Data are presented as means \pm S.E. ${ }^{* * * P}<0.001$ compared to the NT (not treated) control; ${ }_{\# \#} \mathrm{P}<0.01$ compared to the scolopendrasin VII alone control. the BMDMs, we examined the roles of ERK and Akt in scolopendrasin VII-induced BMDM chemotaxis using a specific inhibitor for each enzyme. Incubation of the BMDMs with the ERK inhibitor PD98059 prior to the addition of scolopendrasin VII almost completely inhibited the peptide-induced BMDM chemotaxis (Fig. 2B), moreover the Akt inhibitor MK-2206 completely blocked scolopendrasin VII-induced chemotaxis. Akt activation is mediated by upstream signaling molecules, and PI3K activity in particular is essential for the activation of Akt (14). We also found that the incubation of the BMDMs with the PI3K inhibitor LY294002 completely inhibited scolopendrasin VII-induced BMDM chemotaxis (Fig. 2B). The results suggest that scolopendrasin VII-induced BMDM chemotaxis is mediated by ERK and PI3K-dependent Akt activity.

\section{Scolopendrasin VII-induced BMDM chemotactic migration is mediated by FPR1}

FPR1 is one of the important chemoattractant GPCRs expressed in BMDMs (15). To test the possible role of FPR1 in scolopendrasin VII-induced chemotaxis, we used the FPR1-selective antagonist cyclosporine $\mathrm{H}$ (16). Scolopendrasin VII-induced BMDM chemotaxis was almost completely inhibited by cyclosporine $\mathrm{H}$ (Fig. 3A), which also completely blocked fMLF-induced BMDM chemotaxis (Fig. 3A). To confirm the role of FPR1 in peptide-induced chemotactic migration, we also tested the effect of scolopendrasin VII on the chemotactic migration of vector- or FPR1-expressing RBL-2H3 cells. Scolopendrasin VII markedly induced the chemotactic migration of the FPR1-expressing RBL-2H3 cells but not that of the vector-expressing cells (Fig. 3B).

\section{Scolopendrasin VII directly binds to FPR1}

Since scolopendrasin VII stimulated the chemotactic migration of the BMDMs via PTX-sensitive G-proteins, and FPR1 plays a role in peptide-induced chemotaxis (Fig. 3), we determined whether or not scolopendrasin VII directly binds to FPR1. For this purpose, we synthesized fluorescein isothiocyanate (FITC)conjugated scolopendrasin VII and incubated the labeled peptide with vector- or FPR1-expressing RBL-2H3 cells. FITC-conjugated scolopendrasin VII did not bind to the vector-express-
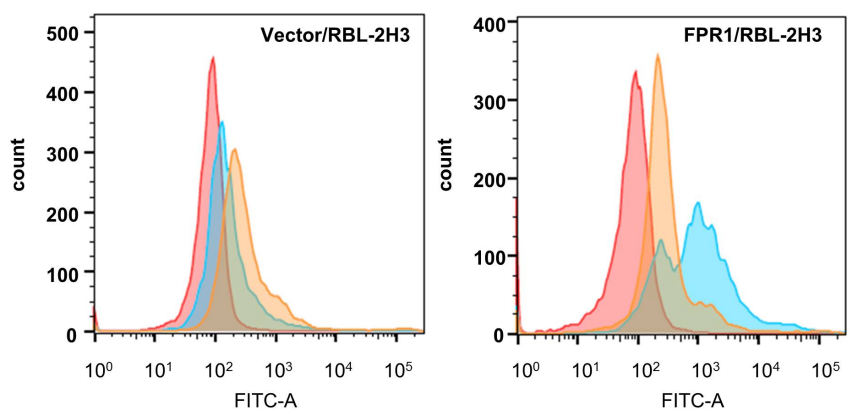

NT

FITC-scolopendrasin VII

Cold scolopendrasin VII + FITC-scolopendrasin VII
Fig. 4. Scolopendrasin VII directly binds to FPR1. FITC-labeled scolopendrasin VII $(1 \mu \mathrm{g} / \mathrm{ml})$ were incubated for $3 \mathrm{~h}$ at $4^{\circ} \mathrm{C}$ with vector- or FPR1-expressing RBL-2H3 cells in the absence or presence of excess unlabeled scolopendrasin VII $(200 \mu \mathrm{g} / \mathrm{ml})$. Binding of the FITC-labeled scolopendrasin VII was determined using a FACS analysis. Data are representative of two independent experiments. 
ing RBL-2H3 cells, but the labeled peptide bound to the FPR1expressing RBL-2H3 cells (Fig. 4). Moreover, the capability of the FITC-conjugated scolopendrasin VII to bind to the FPR1-expressing RBL-2H3 cells was blocked by the addition of the unlabeled scolopendrasin VII (Fig. 4). The results indicate that scolopendrasin VII directly binds to FPR1, resulting in chemotactic migration.

\section{DISCUSSION}

Although FPR2 can recognize AMPs such as LL-37 and $\operatorname{CRAMP}(7,17)$, it has not been reported whether FPR1 can detect an AMP. In this study, we demonstrated that FPR1 detects one of the AMPs derived from Scolopendra subspinipes mutilans, scolopendrasin VII. The binding of scolopendrasin VII to FPR1 elicits actin polymerization, resulting in the chemotactic migration of the macrophages (Fig. 1). In terms of the chemotactic activity in macrophages, several other AMPs derived from Scolopendra subspinipes mutilans also markedly induced macrophage chemotaxis (data not shown). The results suggest that AMPs from Scolopendra subspinipes mutilans may carry immune modulating activity in macrophages.

On the signaling pathway downstream of FPR1, we found that scolopendrasin VII stimulates both ERK and Akt activity, and that these activities are required for the chemotactic migration of the cells (Fig. 2). Previous reports demonstrated that the activation of FPR 1 by fMLF and other agonists induces a diverse range of signaling pathways that includes intracellular calcium increase and several kinase activations $(1,2)$. Intracellular calcium increase is associated with an increased production of reactive oxygen species and heightened bactericidal activity (18). In this study, however, we observed that scolopendrasin VII did not result in an intracellular calcium increase in the macrophages, nor did it evoke a generation of reactive oxygen species from the macrophages (data not shown). We already showed that FPR1 can be differentially regulated by different peptide ligands in a ligand-selective manner (19). Taken together, our results and previous findings show that scolopendrasin VII may selectively regulate FPR1-induced signaling in a ligand-selective manner.

AMPs carry well-conserved common characteristics including an amphipathic structure and a positive charge (20). In addition to bactericidal activity, AMPs may show several important biological activities including the regulation of innate immune responses (21). It has been reported that LL-37 reduced LPS-induced production of TNF- $\alpha$, but augmented the expression of CXCR4, CCR2, and IL8RB from macrophages (21); LL-37 also enhanced IL-8 production in epithelial cells (21). LL-37 may contribute to a regulation of an immune response by recruiting immune cells into an infection site (21). In this study, we demonstrated that one of the AMPs from Scolopendra subspinipes mutilans recruits macrophages via FPR1, a wellknown chemotactic receptor, and our results suggest that AMP can recruit immune cells into an event area by using FPR1.

\section{MATERIALS AND METHODS}

\author{
Materials \\ Scolopendrasin VII (sequence: FCTCNVKGFNAKNKRGIIYP- \\ $\mathrm{NH}_{2}$ ), FITC-conjugated scolopendrasin VII, and WKYMVm were \\ synthesized from Anygen (Gwangju, Korea) with a purity $>$ \\ 99.6\%. fMLF and cyclosporine $\mathrm{H}$ were purchased from Enzo \\ Life Sciences, Inc. (Farmingdale, NY, USA). Rhodamine-phal- \\ loidin was obtained from Life Technologies (Carlsbad, CA, \\ USA). Boyden chambers were purchased from Neuroprobe \\ Inc. (Gaithersburg, MD, USA). Anti-phospho-Akt, anti-phos- \\ pho-ERK, and anti-actin antibodies were obtained from Cell \\ Signaling Technology (Beverly, MA, USA).
}

\section{Generation of BMDMs}

The bone marrow cells were isolated by flushing the femurs and tibias of wild-type C57BL 6 mice, 5 weeks to 7 weeks of age, with ice-cold PBS. Bone marrow progenitor cells were cultured in $10 \%$ FBS containing $\alpha$-MEM with $30 \mathrm{ng} / \mathrm{ml}$ M-CSF (Peprotech, Rocky Hill, NJ, USA) under standard incubator conditions for 1 day. The non-adherent cells were removed, and the $10 \%$ FBS containing $\alpha-M E M$ with $30 \mathrm{ng} / \mathrm{ml} \mathrm{M-CSF}$ was added, and the cells were subsequently maintained for 3 days.

\section{Chemotaxis assay}

Chemotaxis assays were performed in accordance with a previous report using a multiwell Boyden chamber $(22,23)$. The mouse BMDMs and the vector- or FPR1-expressing RBL-2H3 cells were applied to different-sized polycarbonate filters ( 5 $\mu \mathrm{m}$ pore size for the BMDMs, $8 \mu \mathrm{m}$ pore size for the RBL-2H3 cells) for $2 \mathrm{~h}$ ( $4 \mathrm{~h}$ for the RBL-2H3 cells) at $37^{\circ} \mathrm{C}$. The migrated cells were stained with hematoxylin (Sigma, St. Louis, MO, USA) and then counted under a light microscope as previously described $(22,23)$

\section{Measurement of actin polymerization}

Actin polymerization was measured in accordance with a previous report (24). The mouse BMDMs $\left(4 \times 10^{4}\right.$ cells/300 $\left.\mu \mathrm{l}\right)$ were briefly stimulated with scolopendrasin VII $(100 \mu \mathrm{g} / \mathrm{ml})$ or $1 \mu \mathrm{M}$ fMLF for $2 \mathrm{~min}$ at $37^{\circ} \mathrm{C}$. The cells were then fixed for 10 min at room temperature in $4 \%$ paraformaldehyde, followed by the addition of PBS, and rhodamine-phalloidin ( 2 unit $/ \mathrm{ml}$ ) was then added for $30 \mathrm{~min}$. The cells were visualized using a Zeiss LSM 500.

\section{Western blot analysis}

The mouse BMDMs were stimulated with $100 \mu \mathrm{g} / \mathrm{ml}$ of scolopendrasin VII for $0 \mathrm{~min}, 2 \mathrm{~min}, 5 \mathrm{~min}, 10 \mathrm{~min}$, and $30 \mathrm{~min}$. The extracted proteins were then separated using $10 \%$ SDSpolyacrylamide gel and blotted onto a nitrocellulose membrane. The membranes were incubated with specific antibodies (antiphospho-Akt, anti-phospho-ERK, or anti-actin), and antigen- antibody complexes were visualized after the membrane was incubated with 1:2,500 diluted goat anti-rabbit IgG antibodies 
that were combined with horseradish peroxidase, whereby detection was achieved using enhanced chemiluminescence as previously described $(25,26)$.

\section{Ligand binding assay}

The scolopendrasin VII ligand binding assay was performed as previously described (27). The vector-expressing or FPR1-expressing RBL-2H3 cells were briefly seeded at $2 \times 10^{5}$ cells per well in a 12-well plate and cultured overnight. After blocking the cells with blocking buffer (33 mM HEPES, pH 7.5, $0.1 \% \mathrm{BSA}$ in RPMI) for $2 \mathrm{~h}, 1 \mu \mathrm{g} / \mathrm{ml}$ of FITC-labeled scolopendrasin VII was added to the cells in a binding buffer (PBS containing $0.1 \% \mathrm{BSA}$ ) in the absence or presence of the unlabeled scolopendrasin VII $(200 \mu \mathrm{g} / \mathrm{ml})$. After incubating the samples for $4 \mathrm{~h}$ at $4^{\circ} \mathrm{C}$ with continuous agitation, the samples were then washed 5 times with ice-cold binding buffer. After adding $300 \mu \mathrm{l}$ of fixation buffer (PBS containing 5\% FBS, $0.1 \%$ sodium azide, $0.1 \%$ paraformaldehyde) to each well, samples were acquired on a FACScantoll flow cytometer, and Flow Jo 7.6.5 was used for the data analysis.

\section{Data analysis}

Results are expressed as mean \pm S.E. The Student's t-test was used to compare individual treatments with their respective control values. Statistical significance was set at $\mathrm{P}<0.05$.

\section{ACKNOWLEDGEMENTS}

This work was carried out with the support of "Cooperative Research Program for Agriculture Science \& Technology Development (Project title: National Agricultural Genome Program, Project No. PJ01033804)" Rural Development Administration, Republic of Korea.

\section{REFERENCES}

1. Ye RD, Boulay F, Wang JM et al (2009) International Union of Basic and Clinical Pharmacology. LXXIII. Nomenclature for the formyl peptide receptor (FPR) family. Pharmacol Rev 61, 119-161

2. Le Y, Murphy PM, and Wang JM (2002) Formyl-peptide receptors revisited. Trends Immunol 23, 541-548

3. Kim SD, Kim YK, Lee HY et al (2010) The agonists of formyl peptide receptors prevent development of severe sepsis after microbial infection. J Immunol 185, 4302-4310

4. Kang HK, Lee HY, Kim MK et al (2005) The synthetic peptide Trp-Lys-Tyr-Met-Val-D-Met inhibits human monocytederived dendritic cell maturation via formyl peptide receptor and formyl peptide receptor-like 2. J Immunol 175, 685-692

5. Kim SD, Kim JM, Jo SH et al (2009) Functional expression of formyl peptide receptor family in human NK cells. J Immunol 183, 5511-5517

6. Hachicha $M$, Pouliot $M$, Petasis NA, and Serhan CN (1999) Lipoxin (LX)A4 and aspirin-triggered 15-epi-LXA4 inhibit tumor necrosis factor 1alpha-initiated neutrophil responses and trafficking: regulators of a cytokine-chemokine axis. J Exp Med 189, 1923-1930

7. De Yang, Chen Q, Schmidt AP et al (2000) LL-37, the neutrophil granule- and epithelial cell-derived cathelicidin, utilizes formyl peptide receptor-like 1 (FPRL1) as a receptor to chemoattract human peripheral blood neutrophils, monocytes, and T cells. J Exp Med 192, 1069-1074

8. Yoo WG, Lee JH, Shin Y et al (2014) Antimicrobial peptides in the centipede Scolopendra subspinipes mutilans. Funct Integr Genomics 14, 275-283

9. Lee JH, Kim IW, Kim SH et al Anticancer activity of the antimicrobial peptide scolopendrasin VII derived from the centipede, Scolopendra subspinipes mutilans. J Microbiol Biotechnol [Epub ahead of print]

10. Howard TH, and Meyer WH (1984) Chemotactic peptide modulation of actin assembly and locomotion in neutrophils. J Cell Biol 98, 1265-1271

11. Phillips R, and Ager A (2002) Activation of pertussis toxin-sensitive CXCL12 (SDF-1) receptors mediates transendothelial migration of $\mathrm{T}$ lymphocytes across lymph node high endothelial cells. Eur J Immunol 32, 837-847

12. Nardelli B, Tiffany HL, Bong GW et al (1999) Characterization of the signal transduction pathway activated in human monocytes and dendritic cells by MPIF-1, a specific ligand for CC chemokine receptor 1. J Immunol 162, 435-444

13. Green SR, Han KH, Chen Y et al (2006) The CC chemokine MCP-1 stimulates surface expression of CX3CR1 and enhances the adhesion of monocytes to fractalkine/CX3CL1 via p38 MAPK. J Immunol 176, 7412-7420

14. Toker A, and Marmiroli S (2014) Signaling specificity in the Akt pathway in biology and disease. Adv Biol Regul 55, 28-38

15. Dai Y, Major J, Novotny M, and Hamilton TA (2005) IL-4 inhibits expression of the formyl peptide receptor gene in mouse peritoneal macrophages. J Interferon Cytokine Res $25,11-19$

16. Wenzel-Seifert K, Grünbaum L, and Seifert R (1991) Differential inhibition of human neutrophil activation by cyclosporins $\mathrm{A}, \mathrm{D}$, and $\mathrm{H}$. Cyclosporin $\mathrm{H}$ is a potent and effective inhibitor of formyl peptide-induced superoxide formation. J Immunol 147, 1940-1946

17. Koczulla R, von Degenfeld G, Kupatt C et al (2003) An angiogenic role for the human peptide antibiotic LL-37/ hCAP-18. J Clin Invest 111, 1665-1672

18. Bréchard S, and Tschirhart EJ (2008) Regulation of superoxide production in neutrophils: role of calcium influx. J Leukoc Biol 84, 1223-1237

19. Bae YS, Song JY, Kim Y et al (2003) Differential activation of formyl peptide receptor signaling by peptide ligands. Mol Pharmacol 64, 841-847

20. Wiesner J, and Vilcinskas A (2010) Antimicrobial peptides: the ancient arm of the human immune system. Virulence 1, 440-464

21. Scott MG, Davidson DJ, Gold MR, Bowdish D, and Hancock RE (2002) The human antimicrobial peptide LL-37 is a multifunctional modulator of innate immune responses. J Immunol 169, 3883-3891

22. Bae YS, Bae H, Kim Y, Lee TG, Suh PG, and Ryu SH (2001) Identification of novel chemoattractant peptides for 
human leukocytes. Blood 97, 2854-2862

23. Lee N, Jung YS, Lee HY et al (2014) Mouse neutrophils express functional umami taste receptor T1R1/T1R3. BMB Rep 47, 649-654

24. Katanaev VL, and Wymann MP (1998) Microquantification of cellular and in vitro $\mathrm{F}$-actin by rhodamine phalloidin fluorescence enhancement. Anal Biochem 264, 185-190

25. Lee HY, Kim SD, Shim JW et al (2008) Serum amyloid A induces CCL2 production via formyl peptide receptor-like 1-mediated signaling in human monocytes. J Immunol $181,4332-4339$

26. Kook M, Lee SK, Kim SD et al (2015) Anti-septic activity of $\alpha$-cubebenoate isolated from Schisandra chinensis. BMB Rep 48, 336-341

27. Kim SD, Lee HY, Shim JW et al (2011) Activation of CXCR2 by extracellular matrix degradation product acetylated Pro-Gly-Pro has therapeutic effects against sepsis. Am J Respir Crit Care Med 184, 243-251 